\title{
PERANan lasykar hizbullah di pRiangan 1945-1948
}

\author{
THE ROLE OF LASYKAR (PARAMILITARY TROOPS) HIZBULLAH \\ IN PRIANGAN 1945-1948
}

\author{
Galun Eka Gemini \\ Kunto Sofianto \\ Pascasarjana Fakultas Ilmu Budaya Universitas Padjadjaran \\ Jalan Raya Jatinangor \\ e-mail: galun_bikerz@yahoo.com
}

\begin{abstract}
Abstrak
Penelitian ini menggambarkan Peranan Lasykar Hizbullah di Priangan dalam kurun waktu 1945 hingga 1948. Untuk merekontruksi permasalahan ini digunakan metode sejarah yang terdiri dari empat tahap, yaitu heuristik, kritik, interpretasi, dan historiografi. Adapun teknik yang digunakan dalam pengumpulan data digunakan studi literatur dan wawancara, yaitu mengkaji sumber-sumber literatur yang berkaitan dengan permasalahan yang diteliti dan mewawancarai saksi sejarah atau pelaku sejarah sebagai narasumbernya. Penelitian ini bertujuan untuk: (1) mengetahui latar belakang terbentuknya Lasykar Hizbullah di Priangan; (2) mengetahui proses terbentuknya Lasykar Hizbullah di Priangan; dan (3) mengetahui peranan Lasykar Hizbullah di Priangan pada masa revolusi kemerdekaan (1945-1948). Hasil penelitian menunjukkan bahwa Lasykar Hizbullah terbentuk pada 10 Januari 1945. Lasykar Hizbullah merupakan organisasi/sayap kepemudaan yang berada di bawah naungan Masyumi Karesidenan Priangan. Lasykar Hizbullah telah memberikan peran penting dalam mempertahankan kemerdekaan Indonesia. Mereka terlibat aktif dalam pertempuran-pertempuran melawan Belanda-Sekutu, seperti Bandung Lautan Api, Agresi Militer Belanda I, menyikapi Perjanjian Renville. Lasykar Hizbullah di Priangan pada perkembangannya terbagi menjadi dua kelompok: pertama, pro-pemerintah dan bergabung dengan TNI-Divisi Siliwangi sebagai hasil dari adanya program fusi badan-badan perjuangan dengan TNI pada 1947; kedua, kontra-pemerintah dan menjelma menjadi Tentara Islam Indonesia pada 1948, benteng terdepan Negara Islam Indonesia bentukan Kartosuwiryo.
\end{abstract}

Kata kunci: sejarah, Hizbullah, Priangan, revolusi kemerdekaan.

\begin{abstract}
This study illustrates the role of Laskar Hizbullah in Priangan in the period 1945 to 1948. In order to reconstruct the problem, this study uses history method which consists of four stages, namely heuristic, criticism, interpretation, and historiography. The techniques of data collection used literature and interviews, including reviewing the sources of literature related to the problems studied and interviewing the witnesses of history or historical actors as the respondents. This study aims to: (1) know the background of the Laskar Hizbullah formation in Priangan; (2) recognize the process of of Lasykar Hizbollah formation in Priangan; and (3) identify the role of Laskar Hizbullah in Priangan during the revolution of independence (1945-1948). The results showed that Laskar Hizbullah was formed on January 10, 1945. It is an organization under the auspices of Masjumi Priangan Residency. Hezbollah army has given an important role in maintaining the independence of Indonesia. They are actively involved in the battles against the Dutch-ally, such as Bandung Sea of Fire, Dutch Military Aggression I, addressing the Renville Agreement. Hezbollah army in Priangan, in its development, is divided into two groups: first, progovernment and join TNI-Siliwangi Division as a result of the fusion program ofstruggle agencies
\end{abstract}


with the military in 1947; second, a counter-government and transformed into Islamic Army of Indonesia in 1948, the fort leading of Indonesian Islamic State of Kartosuwiryo formation.

Keywords: history, Hizbullah, Priangan, independence Revolution.

\section{A. PENDAHULUAN}

Selama ini peran sentral ulamasantri dalam catatan-catatan sejarah Indonesia masih cenderung terpinggirkan, termasuk peran sentral ulama-santri pada masa revolusi kemerdekaan Indonesia. Berbagai kajian pada tingkat lokal dan regional mengenai perjuangan kemerdekaan yang muncul belakangan ini tidak banyak menyebutkannya, dan sebagian lagi bahkan mengabaikannya. Sebaliknya, eksistensi kelompok netral agama/nasionalis sekuler mendapatkan perhatian yang lebih dalam penulisan sejarah Indonesia.

Kenyataan semacam ini tidak menutup kemungkinan akan memunculkan anggapan bahwa terbentuknya negara Republik Indonesia menjadi sebuah negara yang merdeka hanya dibidani oleh kaum nasionalis/netral agama saja. Dengan begitu, sejarah akan terkesan bersifat memihak (tendensius) dan tidak objektif.

Untuk itu, penulisan-penulisan sejarah yang memfokuskan kajiannya terhadap eksistensi ulama-santri atau kelompok nasionalis agama dalam panggung sejarah nasional Indonesia dirasa sangat diperlukan dan bermanfaat dalam rangka memperkaya khazanah pengetahuan sejarah Indonesia, baik yang bersifat lokal atau pun nasional.

Misal pada konteks periode revolusi kemerdekaan Indonesia di tingkat lokal, eksistensi ulama-santri di Priangan memiliki peran penting dalam upaya menegakkan kemerdekaan Negara Kesatuan Republik Indonesia. Bersama badan-badan perjuangan yang ada saat itu, para ulama-santri terlibat aktif melawan Sekutu-Belanda yang hendak menguasai kembali Negara Kesatuan Republik Indonesia. Oleh karenanya, tidak salah bila Dengel (2011: 1) menyebut ulama-santri sebagai salah satu "katalisator" atau pembuka jalan bagi lahirnya nasionalisme dan tegaknya kemerdekaan Indonesia.

Dalam historiografi Indonesia, revolusi kemerdekaan, acap kali dimaknai sebagai cerita perang. Suatu masa yang dilumuri oleh berbagai macam konflik (politik) kenegaraan antara Indonesia dengan Sekutu-Belanda.

Perang menjadi jalan penyelesaian terakhir tatkala jalur diplomasi gagal ditempuh. Perang dilakukan melalui perlawanan mengangkat senjata.

Dalam situasi yang demikian memunculkan badan-badan perjuangan di Indonesia sebagai counter terhadap pasukan Belanda-Sekutu itu. Badan-badan perjuangan tersebut berasal dari berbagai elemen masyarakat yang pada dasarnya beragam secara etnis, jenis kelamin ${ }^{1}$, agama, budaya, dan lain-lain. Kendati pun demikian, secara prinsip memiliki kesamaan tujuan, yaitu untuk berjuang mempertahankan kemerdekaan Indonesia.

Dalam buku "Siliwangi dari Masa ke Masa", tercatat sebanyak 18 badan perjuangan yang terdapat di Jawa Barat pada saat itu. Satu di antaranya adalah Lasykar Hizbullah (Disjarahdam IV Siliwangi, 1979: 23-24).

Lasykar Hizbullah berarti tentara Allah $($ Hizb Allah = tentara Allah). Lasykar Hizbullah merupakan badan perjuangan atau kelasykaran yang terdiri dari pemuda-pemuda Islam. Biasanya mereka berasal dari pondok-pondok

${ }^{1}$ Di dalam barisan perjuangan tidak hanya diikuti oleh kaum laki-laki saja, tetapi kaum ibu/perempuan juga turut berjuang bersamasama dalam menegakan kemerdekaan Indonesia. Para "srikandi" itu terhimpun ke dalam Lasykar Wanita Indonesia (Lasywi). Di Jawa Barat, Lasywi dibentuk pada 12 September 1945 di bawah pimpinan Ny. Soemirah Djati (istri Aroedji Kartawinata) (Suryanegara, 2010: 211). 
pesantren (santri), atau madrasahmadrasah.

Sehubungan dengan ini, tulisan mengenai peranan Lasykar Hizbullah di Priangan (1945-1948) perlu diangkat, karena tulisan yang komprehensif dengan tema seperti ini belum ditemukan, sehingga dapat memberikan khazanah baru dalam historiografi lokal ataupun Indonesia pada umumnya.

Ruang lingkup wilayah Priangan yang diambil dalam penelitian ini adalah wilayah Bandung dan Garut. Sedangkan alasan pembatasan kurun waktu penelitian mulai tahun 1945 hingga tahun 1948, dikarenakan beberapa pertimbangan. Tahun 1945 dijadikan sebagai titik awal dalam penelitian ini karena tahun tersebut merupakan awal terbentuknya Lasykar Hizbullah di Priangan. Sementara tahun 1948 menjadi titik akhir penelitian karena tahun tersebut menandai berakhirnya eksistensi Lasykar Hizbullah di Priangan.

Berdasarkan pemaparan di atas, terdapat beberapa permasalahan yang akan dibahas. Permasalahan pokoknya adalah "Bagaimana Peranan Lasykar Hizbullah di Priangan pada masa revolusi kemerdekaan Indonesia dalam kurun waktu 19451948?". Untuk memudahkan dan mengarahkan dalam pembahasan, maka diajukan beberapa pertanyaan sekaligus sebagai rumusan masalah yang akan dibahas dalam penelitian ini antara lain: (1) Apa latar belakang berdirinya Lasykar Hizbullah di Priangan?; (2) Bagaimana proses terbentuknya Lasykar Hizbullah di Priangan?; (3) Bagaimana peranannya pada masa revolusi kemerdekaan Indonesia (1945-1948)?

Tujuan dari penelitian ini dimaksudkan untuk: (1) mengetahui latar belakang berdirinya Lasykar Hizbullah di Priangan; (2) mengetahui proses terbentuknya Lasykar Hizbullah di Priangan; (3) mengeahui peranan Lasykar Hizbullah pada masa revolusi kemerdekaan Indonesia.

Dalam mengkaji permasalahan yang akan dibahas, peneliti menggunakan literatur terdahulu sebagai sumber rujukan dalam penelitian ini. Walaupun pada prinsipnya, sumber-sumber yang menjelaskan mengenai Lasykar Hizbullah secara eksplisit sangat sedikit untuk ditemukan. Akan tetapi, penulis mencoba memanfaatkan dari sumber-sumber terdahulu yang di dalamnya menyinggung mengenai Lasykar Hizbullah. Buku pertama, berjudul "Siliwangi dari Masa ke Masa”. Buku ini ditulis oleh TIM yang dibentuk oleh Dinas Sejarah Kodam (Disjarahdam) IV Divisi Siliwangi, cetakan ke-2 pada 1979. Dari segi konten, buku setebal 657 halaman itu mengupas mengenai TNI-IV Divisi Siliwangi - yang sekarang berubah menjadi Kodam III Siliwangi - dari mulai sejarah, struktur organisasi, lembaga-lembaga korps, dan tentu peranannya dalam mengawal kedaulatan Negara Kesatuan Republik Indonesia. Pada saat suasana revolusi kemedekan berlangsung (menghadapi berbagai macam gangguan baik dari dalam negeri maupun luar negeri), TNI-Divisi Siliwangi kerapkali bermanunggal dengan badan-badan perjuangan lainnya seperti Lasykar Hizbullah. Terdapat juga penjelasan tentang peranan badan-badan perjuangan yang di dalamnya memuat Lasykar Hizbullah. Oleh karena itu buku ini sangat relevan dengan penelitian yang sedang dikaji. Sebab, di dalamnya menyinggung pula mengenai eksistensi Lasykar Hizbullah di Priangan.

Buku kedua yang digunakan sebagai sumber rujukan adalah karya Holk $\mathrm{H}$. Dengel Darul Islam-NII dan Kartosuwirjo: Angan-angan yang Gagal diterbitkan tahun 2011 oleh Pustaka Sinar Harapan. Buku ini mengungkap tentang sosok Kartosuwirjo secara personal; track record-nya mulai pada awal masa pergerakan nasional, masa pendudukan Jepang, masa revolusi sampai akhir hayatnya ketika dihadapkan pada Mahkamah Angkatan Darat. Buku ini telah memberikan informasi terutama permasalahan DI/TII di Jawa Barat yang ada hubungannya dengan penelitian ini. 
Mengingat cikal bakal terbentuknya Tentara Islam Indonesia (TII) bersumber dari kekuatan Lasykar Hizbullah. Dapat dipastikan di dalam buku ber-cover hijau ini mengupas Lasykar Hizbullah di Priangan.

Ada pula buku karangan Zainul Milal Bizawie yang berjudul "Laskar Ulama-Santri \& Resolusi Jihad". Buku ini diterbitkan oleh Pustaka Compass pada 2014. Buku setebal 419 halaman ini cukup banyak membahas mengenai eksistensi Lasykar Hizbullah pada tingkat nasional mulai dari pembentukan Lasykar Hizbullah oleh Jepang di akhir pendudukannya, berikut peranannya pada saat peristiwa AMB I, menyikapi Perjanjian Renville, dan fusi dengan TNI. Maka keberadaan buku ini sangat relevan dengan penelitian yang penulis lakukan, sehingga dapat dijadikan bahan rujukan oleh penulis dalam penelitian ini.

Berikutnya adalah karangan $\mathrm{KH}$. Mansyur Suryanegara berjudul "API Sejarah 2". Buku ini diterbitkan tahun 2010 oleh Grafindo Media Pratama. Buku setebal 588 halaman ini berusaha menyajikan tentang fakta sejarah kiprah para ulama dan santri yang masih tersembunyi dalam menegakkan kemerdekaan Indonesia. Dengan ulasan konten materi yang terfokus terhadap satu titik permasalahan dan sistematis, yaitu mengupas peranan ulama dan santri dalam percaturan politik Indonesia yang secara temporalnya cukup panjang; dari masa pergerakan, hingga era reformasi berlangsung. Maka sangatlah wajar bila buku ini mendapat predikat "Best Seller" dalam sepanjang sejarahnya. Kaitannya dengan penelitian ini pun tampak kentara, KH. Ahmad Mansyur banyak memaparkan usaha-usaha para ulama dan santri dalam perjuangan melawan Sekutu-Belanda pada periode revolusi kemerdekaan. Misalnya, perlawanan yang dilakukan oleh ulamasantri melawan sekutu yang terjadi di Jl. Lengkong Besar yang berlanjut pada peristiwa Bandung Lautan Api pada 23 Maret 1946.
Dari tinjauan atas kajian di atas dapat diketahui bahwa buku-buku yang terkait dengan Peranan Lasykar Hizbullah boleh dikatakan cukup banyak, terutama berkenaan dengan masalah perjuangan santri atau ulama dalam menegakkan dan mempertahankan kemerdekaan Indonesia. Namun, buku-buku atau tulisan yang secara khusus menulis Lasykar Hizbullah di Priangan, belum pernah ada. Kalau pun ada itu hanya sebagian kecil saja yang belum tersusun secara khusus dan utuh.

Alasan inilah yang kemudian mendorong penulis untuk melakukan penelitian dengan judul "Peranan Lasykar Hizbullah di Priangan pada Masa Revolusi Kemerdekaan Indonesia (1945-1948)".

\section{B. METODE PENELITIAN}

Dengan mengacu pada maksud dan tujuan penelitian, penelitian ini menggunakan prosedur yang lazimnya digunakan dalam penelitian sejarah. Tujuannya adalah untuk membuat rekontruksi masa lampau secara sistematis dan objektif (Herlina, 2011:1). Tujuan ini dicapai dengan menggunakan metode sejarah. "Metode sejarah yaitu proses menguji dan menganalisis secara kritis rekaman dan peninggalan agar peristiwa yang terjadi di masa lampau dapat direkontruksi secara imajinatif" (Gottschalk, 1985:32).

Tahapan pertama dari metode sejarah adalah heuristik yakni proses mencari, menemukan dan menghimpun sumber sejarah yang relevan dengan pokok masalah yang sedang diteliti. Untuk mendapatkan sumber tersebut penulis langsung terjun ke lapangan, baik mendatangi para pelaku atau saksi sejarah yang masih ada, Dinas dan Perpustakaan Sejarah TNI AD, maupun Perpustakaan Republik Indonesia dan Arsip Nasional Republik Indonesia. Setelah sumber sejarah terhimpun, proses selanjutnya dilakukan kritik terhadap sumber. Kritik sumber dibagi menjadi dua, yaitu kritik eksternal dan kritik internal. Kritik eksternal dilakukan untuk menentukan 
otentisitas sumber, sedangkan kritik internal ditempuh untuk menentukan kredibilitas data/informasi. Selain itu dilakukan juga proses koroborasi yakni pendukungan data yang ada dalam sumber tersebut dengan sumber lainnya yang bersifat independen. Dengan proses seperti itu akhirnya diperoleh sumber yang kredibel atau dapat dipercaya.

Data yang telah lolos dari tahapan kritik kemudian dilakukan interpretasi. Interpretasi merupakan tahapan menafsirkan informasi dan pemberian makna, sehingga fakta-fakta tersebut menjelaskan objek studi secara jelas dan lengkap. Selanjutnya dilakukan tahapan terakhir, yaitu historiografi atau penulisan sejarah. Hasil interpretasi atas sumbersumber yang terdeteksi sedemikian rupa ditulis menjadi sebuah tulisan sejarah yang objektif, terarah dan sistematis, sehingga dapat dipertanggungjawabkan secara ilmiah kebenarannya.

Selain itu untuk memeroleh kajian yang lebih baik dalam upaya mewujudkan hasil penelitian sejarah yang dapat dipertanggungjawabkan secara ilmiah, penelitian ini menggunakan pendekatan dari ilmu sosiologi, berupa: konsep dan teori.

Konsep peranan (role) diterapkan dalam penelitian ini. Peranan merupakan aspek dinamis dari kedudukan. Menurut Soekanto (1982: 239), kedudukan diartikan sebagai tempat atau posisi seseorang dalam suatu kelompok sosial. Apabila seseorang melaksanakan hak dan kewajibannya sesuai dengan kedudukannya dalam masyarakat, maka ia telah menjalankan sebuah peranan.

Dalam hal ini posisi Lasykar Hizbullah sebagai benteng pertahanan agama (Islam) dan negara, maka kewajibannya adalah menjalankan tugasnya sebagai alat pertahanan dalam mempertahankan agama (Islam) dan negara dari kekuasaan "kafir" (SekutuBelanda).

Dalam panggung sejarah revolusi Indonesia, terjadi perlawanan yang dilakukan Lasykar Hizbullah terhadap Sekutu dan Belanda. Aksi perlawanan yang dialami oleh Lasykar Hizbullah itu tergolong ke dalam konflik. Untuk menjelaskan konflik yang terjadi, maka digunakan teori konflik dari Ralf Dahrendrof.

Teori konflik relevan untuk menjelaskan berbagai fenomena seperti perselisihan, perang, revolusi, dan sebagainya yang menggambarkan adanya pertentangan, baik secara kolektif ataupun individu.

Dahrendrof berpandangan bahwa teori konflik harus menguji konflik kepentingan dan penggunaan kekerasan yang mengikat masyarakat bersama di bawah tekanan itu. (Ritzer, G. dan Douglas J. Goodman, 2011: 153-154). Penyelesaian konflik biasanya dapat ditempuh melalui dua cara, yaitu melalui kekerasan dan melalui diplomasi. Ketika jalur diplomasi gagal ditempuh, jalan perang atau kekerasan menjadi jalan penyelesaiannya.

Dalam panggung sejarah revolusi kemerdekaan Indonesia terjadi beberapa konflik yang mengemuka. Konflik-konflik tersebut bukan hanya melibatkan tentara regular pemerintah (TNI), tetapi juga badan-badan perjuangan yang ada saat itu termasuk Lasykar Hizbullah.

\section{HASIL DAN BAHASAN \\ 1. Proses terbentuknya Lasykar Hizbullah di Priangan \\ Pada tanggal 10 Desember 1944} sampai 19 Januari 1945, wakil-wakil PB. Masyumi mengadakan perjalanan keliling ke seluruh daerah karesidenan se-Jawa dan Madura, dengan mengunjungi pusat-pusat kota penting di Jawa dan Madura. Salah satu tujuannya adalah: (1) menyiapkan pembentukan panitia pusat Masyumi daerah; (2) memberikan penjelasan tentang berdirinya Lasykar Hizbullah, diikuti perintah untuk membentuk Hizbullah di daerah; (3) memeriksa calon-calon anggota Hizbullah yang akan dilatih di Cibarusa Bekasi (Soeara Moeslimin, No. 2, 15 Januari 1945). 
Paparan di atas telah memberi arti bahwa kedudukan Lasykar Hizbullah merupakan organisasi sayap kepemudaan yang secara hierarki berada di bawah naungan Masyumi. Kedudukan Lasykar Hizbullah semacam itu menurut hemat penulis ibarat GP. Anshor dalam lingkup Nahdlatul Ulama (NU).

Ada beberapa faktor PB. Masyumi menjadikan Jawa dan Madura sebagai sasaran utama dalam merealisasikan agendanya itu. Pertama, karena jumlah penduduk di Jawa dan Madura terhitung paling padat daripada penduduk lainnya di Indonesia, sehingga dianggap sebagai sumber yang potensial. Selanjutnya keberadaan pesantren-pesantren atau santri yang tersebar luas di Jawa dan Madura menjadikan upaya sosialisasi ini dianggap berjalan secara efektif dan mendapatkan apresiasi tinggi dari masyarakat. Selain itu, mengingat Jawa sebagai "jantung" dari wilayah Indonesia.

Dalam konteks di Priangan, umat Islam di Priangan menyambut baik mengenai usulan pembentukan Lasykar Hizbullah. Perjuangan-perjuangan bersenjata yang dipelopori oleh ulama terdahulu telah menginspirasi umat Islam Priangan untuk mendukung dan bersifat akomodatif dalam terbentuknya Lasykar Hizbullah di Priangan. Misal, terinspirasi oleh perlawanan yang dipelopori $\mathrm{KH}$. Zaenal Mustafa di Sukamanah Tasikmalaya, Pemberontakan Peta di Pangalengan Bandung, dan sebagainya.

Pada tanggal 10 Januari 1945, di ruangan Gedung Dai Tooa Kaikan di Bandung-atas usaha panitia Masyumi Shuu Priangan-diselenggarakan pertemuan dengan para utusan Masyumi pusat yang terdiri atas KH. Faried Ma'roef, Zainal Arifin, diikuti pula oleh A. Hamid Ono, Kenchoo, Shichoo, para ulama terkemuka Shuu Priangan, dan berpuluh-puluh orang calon anggota Lasykar Hizbullah. Pertemuan itu dipimpin langsung oleh $\mathrm{KH}$. Anwar Musaddad dari Garut (Asia Raya, No. 11. 12 Januari 1945). Dari pertemuan itu dihasilkan sebuah kesepakatan tentang terbentuknya Lasykar Hizbullah untuk Karesidenan Priangan dengan tokohnya Kamran, Utarya, KH. Anwar Musaddad (Disjarahdam IV/Siliwangi, 1979: 23).

Zainal Arifin (Pemimpin Besar Hizbullah) memberi penjelasan mengenai barisan Hizbullah. Inti dari pembicaraannya itu adalah membangkitkan semangat kepada umat Islam, agar jangan sampai umat Islam dijajah oleh sekutu, yakni sesudah mengalami penjajahan sejak lama ${ }^{2}$, maka diperlukan kekuatan dari umat Islam untuk menangkalnya dalam perjuangan. Tujuan Lasykar Hizbullah yakni berjuang dalam peperangan serta membangun masyarakat Indonesia baru bersama-sama dengan Peta, Heiho, Seinendan, Keibodan, dan sebagainya (Asia Raya, No. 11. 12 Januari 1945).

Perekrutan anggota Hizbullah di wilayah Priangan berasal dari organisasiorganisasi dan sekolah-sekolah Islam seperti Muhammadiyah, NU, Persis, dan juga lembaga pendidikan yang ada, seperti dari beberapa pondok pesantren di sekitar Priangan. Perekrutan anggota lasykar diambil dari para pemuda yang memiliki keberanian untuk berperang, karena meskipun banyak para pemuda yang berada pada usia produktif saat itu, namun tidak semuanya memiliki hasrat dan keberanian untuk sama-sama terlibat ke dalam kancah peperangan melawan penjajah (Suryana, wawancara tanggal 10 Juni 2015).

Perekrutan anggota Hizbullah sesuai dengan keputusan PB. Masyumi, harus melalui tes, yaitu pengetahuan dan pengamalan agama Islam, dan kesehatan serta keterampilan fisik. Angkatan pertama dapat lulus masuk Hizbullah Priangan sebanyak \pm 25 pemuda, yang didominasi dari Kabupaten-kabupaten Garut, Tasikmalaya, Ciamis, juga Bandung. Sayang, mengenai proses terbentuknya

2 Saya tidak menyebutnya Indonesia dijajah oleh Belanda 350 tahun, karena itu adalah "mitos" dan tidak mendasarkan pada fakta sejarah. 
Lasykar Hizbullah di tiap kabupaten sekitar Karesidenan Priangan serta namanama peserta yang mengikuti pelatihan kemiliteran di Cibarusa-Bekasi tidak dapat disebutkan, disebabkan data atau sumber yang tidak ditemukan. Hanya sebagian kecil saja mengenai daftar nama/peserta yang mengikuti pelatihan kemiliteran di Cibarusa-Bekasi mewakili Karesidenan Priangan antara lain: H. Machdar, Huseinsyah, Zainul Abidin, Ajengan Icih, dan Kamran (Machdar, wawancara tanggal 13 Juni 2015).

Pada tanggal 28 Februari 1945 seluruh anggota Hizbullah Shuu Priangan dikirim ke Cibarusa - Bekasi, untuk mengikuti latihan kemiliteran bersama seluruh calon anggota Lasykar Hizbullah se-Jawa dan Madura. Biaya transportasi, perlengkapan dan pelatihan ditanggung oleh Pimpinan Masyumi masing-masing daerah karesidenan. Anggota Hizbullah yang mengikuti pelatihan di Cibarusa ini semuanya berjumlah 500 orang. Selama pendidikan berlangsung mereka ditempatkan di barak-barak bambu. Latihan Perang Hizbullah ini dibuka oleh pimpinan Jawa Gunseikan, pada tanggal 28 Februari 1945, dan dihadiri oleh para tokoh Masyumi dan pembesar militer Jepang (Machdar, wawancara tanggal 13 Juni 2015).

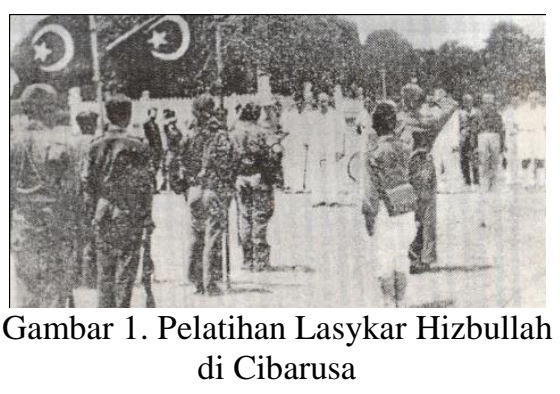

Sumber: Suryanegara, 1996: 145.

Pelatihan perang ini dilaksanakan selama 3 bulan. Bulan pertama diisi dengan latihan rohani disertai latihan dasar keprajuritan. Bulan kedua dengan latihan jasmani. Lalu, bulan ketiga memperkuat latihan rohani dan jasmani. Maksud pembagian waktu seperti ini, diharapkan pada bulan-bulan pertama latihan para calon anggota Lasykar Hizbullah memiliki semangat persatuan yang sebulat-bulatnya dan memperkuat ketauhidannya.

Sementara di bidang fisik dan kemiliteran, pelatihan diberikan oleh para perwira tentara Jepang dan Peta yang dipimpin langsung oleh Kapten Yanagawa ${ }^{3}$ (Notosusanto, 1979: 46), sedangkan di bidang spiritual dipercayakan kepada K.H. Mustafa Kamil dari Singaparna (Soeara Moeslimin, No. 10. 1 Mei 1945).

Seluruh tahapan latihan baik rohani maupun jasmani dilakukan untuk menuntut kebulatan semangat perjuangan dengan latar semangat keagamaan, keprajuritan, dan cinta tanah air. Dalam Soeara Moeslimin, No. 23 dan 24, 15 Desember 1944, disebutkan macamnya latihan rohani yaitu:

1) Mempertebal semangat ke-Islaman, seperti tauhid dan hukumhukum agama Islam;

2) Mendidik semangat Dai Nipon;

3) Mempertinggi akhlak agar secara sukarela mengerjakan berbagai macam kepentingan umum dan mengerjakan ibadah-ibadah yang ditentukan;

4) Mempertebal dan membangkitkan semangat bekerja keras.

Sementara untuk latihan jasmani, yaitu:

1) Mencegah serangan dari udara dan bahaya kebakaran, serta melindungi penduduk, juga menangkap mata-mata musuh;

2) Mengadakan latihan mengerahkan tenaga pada waktu-waktu penting atau darurat;

3) Latihan keprajuritan semaksimal mungkin dan selengkaplengkapnya.

Pada tanggal 20 Mei 1945 Pelatihan militer bagi Lasykar Hizbullah di Cibarusa ditutup oleh P.T. Nomura Kikakukatyco mewakili pemerintah militer Jepang. Sementara itu, dari pihak Masyumi (Indonesia) hadir K.H. Wahid Hasyim

\footnotetext{
${ }^{3}$ Sebelumnya tercatat sebagai pimpinan dalam penyelenggaraan latihan militer bagi kesatuan militer Peta.
} 
yang kedudukannya sebagai "ketua muda" PB. Masyumi. Semua anggota Lasykar Hizbullah yang ikut pelatihan di Cibarusa diwajibkan berikrar: (1) Menyerahkan dirinya secara bulat pada Masyumi; (2) Harus mampu mendirikan Hizbullah di daerah tempat tinggalnya dan menunjuk kepala atau pemimpin yang senantiasa berhubungan dengan pemimpin daerah atau kantor Shuuchoo; dan (3) Tiap-tiap anggota Hizbullah diharuskan menjalin kerjasama dengan madrasah-madrasah, pesantren-pesantren, serta para pemuda Islam di daerahnya dalam rangka untuk mengulangi dan menyiarkan hasil latihan yang telah diperolehnya; dan (4) tiap-tiap anggota Hizbullah yang telah dilatih wajib menjaga dirinya dan kehormatannya sebagai Tentara Allah (Soeara Moeslimin, No. 10. 1Mei 1945).

Pemilihan Cibarusa-Bekasi sebagai tempat latihan militer Lasykar Hizbullah menurut hemat penulis disebabkan tempat tersebut dirasa sangat strategis, di antaranya karena masih banyak hutan dan terdapat sebuah lapangan yang cocok untuk melakukan pelatihan. Keberadaan hutan sangat mendukung dalam kegiatan pelatihan tersebut, mengingat pola perlawanan yang diterapkan Jepang sejak pembentukan Peta pada 1943 menerapkan sistem gerilya. Faktor lainnya adalah karena pertimbangan jarak antara Bekasi dan Jakarta sebagai pusat pemerintahan militer Jepang, sekaligus pusat di mana kantor PB. Masyumi berada yang tidak terlalu jauh, sehingga memudahkan dalam hal pengurusan administrasi atau hal-hal yang terkait dengan pelatihan tersebut.

Sepulangnya latihan dari Cibarusa, di daerah Priangan tetap diadakan pembinaan dan pelatihan kemiliteran. Pihak-pihak yang duduk sebagai pelatih adalah para kyai dan ulama yang cukup dan cakap dalam keagamaannya. Latihan pematangan ini umumnya dilakukan di pesantren-pesantren atau di pondokpondok kecil tempat belajar mengaji seperti yang terdapat di daerah Cikole Bandung Utara di bawah pimpinan
Ajengan Icih (Suryana, wawancara tanggal 10 Juni 2015), di Pesantren daerah Cicukang Cigondewah di bawah Ajengan Aceng (Machdar, wawancara tanggal 13 Juni 2015).

Di luar Bandung, tepatnya di sekitar Garut, pelatihan dan perekrutan anggota Lasykar Hizbullah berlangsung di pondokpondok pesantren yakni: di Institut Suffah yang berada di daerah Malangbong-Garut di bawah pimpinan Ateng Djaelani (Dengel, 2011: 56); Pesantren Al-Falah Biru (Garut) juga pernah menjadi lahan pelatihan dan perekrutan anggota Lasykar Hizbullah di bawah asuhan Syaikhuna Badruzzaman; di wilayah Garut lainnya, pelatihan dan perekrutan Lasykar Hizbullah dilakukan di Pesantren Darussalam, Cipari Garut. KH. Anwar Musaddad dan KH. Yusuf Taujiri pengasuh Pesantren Darussalam dan Cipari pernah melatih sekitar 200 santrinya yang tergabung dalam Lasykar Hizbullah dan menjadikan rumahnya sebagai dapur umum bagi lasykar tersebut (Muhsin Z, 2015: 3).

Adapun materinya terdiri atas dua macam, sebagaimana latihan yang diselenggarakan para pendahulunya. Ada latihan rohani dan latihan jasmani. Pada latihan rohani dipelajari ilmu "kanuragan" melalui olah pernapasan, sedangkan jasmani (kemiliteran) Lasykar Hizbullah dilatih mulai teknik baris-berbaris, teknik dasar kemiliteran, pembuatan bahan peledak, hingga menggunakan bambu runcing dan pentungan kayu serta teknik penggunan senjata berat di medan pertempuran (Soeara Moeslimin No. 6. 15 Maret 1945 ).

Komposisi anggota Lasykar Hizbullah pada tahun-tahun berikutnya mengalami perkembangan. Hubungan kyai dan santri atau masyarakat yang bersifat "patron-client" memudahkan kyai dalam mobilisasi massa. Kedudukan kyai sebagai elite agama memiliki kharisma dan peran yang tinggi dalam masyarakat. Masyarakat bukan hanya menganggap sosok kyai sebagai lambang kewahyuan, tetapi juga 
sebagai sosok orang tua yang cakap mengatasi berbagai persoalan hidup yang terjadi di masyarakat, sehingga apa yang menjadi fatwanya kerapkali diikuti dan diamalkan oleh masyarakat tersebut. Tingginya kesadaran yang dimiliki para pemuda Islam dan santri dalam membela tanah air dari cengkraman penjajah menjadi penopang Lasykar Hizbullah mengalami pertambahan (perkembangan) jumlah anggota di tiap daerah, termasuk di Karesidenan Priangan.

Alasan lainnya karena keanggotaan Hizbullah mendapatkan dukungan dari Gerakan Pemuda Islam Indonesia (GPII) yang merupakan "adik kandung-nya" dalam tubuh Masyumi (Djiwa Islam, No. Setahun GPII, 1946-1948).

\section{Lasykar Hizbullah di Priangan dalam Menghalau pasukan Belanda-Sekutu}

a. Melakukan Pelucutan Senjata dari Tentara Jepang

Secara faktual, Peristiwa Proklamasi yang dikumandangkan tanggal 17 Agustus 1945 tidak menjamin Indonesia menjadi negara merdeka. Belanda dan Sekutu yang telah berhasil mengalahkan Jepang mencoba kembali masuk dan menduduki kembali Indonesia dengan memboncengi NICA (Netherlands Indies Civil Administration).

Kesadaran adanya ancaman terhadap kemerdekaan Indonesia semakin jelas dirasakan ketika lepasnya para tawanan perang Belanda dari penjara-penjara Jepang serta pendudukan beberapa titik wilayah dan tempat oleh bekas para tawanan perang Belanda. Oleh karena itu, untuk mempersenjatai diri dalam upaya menghadapi kemungkinan terburuk ini, pihak Indonesia mempersiapkan kekuatan melalui beragam cara yakni: melakukan pelucutan senjata dari tentara Jepang dan membentuk Markas Daerah Perjuangan Pertahanan Priangan (MDPPP) sebagai wadah koordinasi badan-badan perjuangan yang ada.

Aksi perebutan senjata tidak terjadi secara serentak antarsatu daerah dengan daerah lainnya. Meski demikian, dapat dipastikan di setiap daerah cenderung melakukan hal serupa dalam mempersenjatai dirinya guna melawan pihak Belanda-Sekutu. Tentunya dengan beragam pola dan bentuk yang tidak sama.

Di Bandung, karena Peta telah dibubarkan dan dilucuti, anggota badanbadan perjuangan - termasuk Lasykar Hizbullah - bersama BKR berusaha merebutnya kembali dari tangan Jepang. Berbagai cara dilakukan untuk mendapatkan kembali pasokan senjata, mulai dengan cara baik-baik atau penyerahan secara sukarela dari pihak Jepang sampai dengan cara perampasan bila cara yang pertama sulit ditempuh. Namun, adakalanya upaya mendapatkan senjata dilakukan dengan cara barter seperti yang pernah terjadi di Bandung Utara (Sundhaussen, 1986:15; Suryana, wawancara tanggal 10 Juni 2015).

Lasykar Hizbullah untuk wilayah Bandung Utara sendiri, sejak masa revolusi kemerdekaan pernah bermarkas di Pesantren Cikapayang. Akibatnya, ketika revolusi berakhir, bangunan pesantren mengalami kerusakan berat, karena kegiatan atau aktivitasnya yang telah dilakukan oleh Lasykar Hizbullah dalam bertempur melawan Belanda (Kusdiana, 2014: 150).

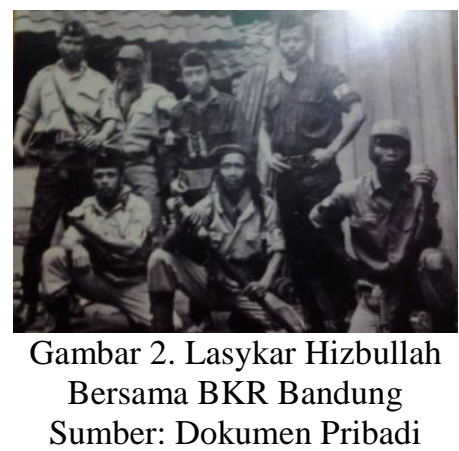

Di Garut, upaya pelucutan senjata terjadi secara sengit di sekitar Hotel Malayu yang berada di daerah Samarang. Hotel Malayu pada masa pendudukan Jepang dijadikan sebagai gudang untuk menyimpan berbagai barang sebagai pemenuhan keberlangsungan pemerintah militer Jepang di Garut. Selain upaya 
pelucutan Lasykar Hizbullah di bawah pimpinan KH. Syaikhuna Badruzzaman bersama masyarakat mengadakan penjarahan terhadap barang-barang yang ada di sana, di antaranya berupa kain, makanan, triplek, seng, cangkul, dan lain sebagainya. (Djudju, wawancara tanggal 3 Juni 2012; koleksi rekaman Fauz Nur'alim).

Pengambilalihan ini dilakukan karena secara geografis letak gudang logistik di Hotel Malayu Samarang tersebut berada dalam wilayah jangkauan gerakan Lasykar Hizbullah dari Pesantren Al-Falah Biru. Lasykar Hizbullah yang melakukan pelucutan senjata itu berjumlah 20 orang di antaranya; Mahbub Sofwan, Aos Subandar, Enis Idris, Raden Didih, Uyun bin Abdul Patah, Hamim Ahyar, Aan Mustopa, Abdul Gholib, Mukhtar, Oom Jaelani, Acep, Aceng Udin, Aceng Amin, Maman, Adar, Ahpud, Bapak Ganda, dan Muhammad Atori. Pengambilalihan gudang logistik di Samarang tersebut menjadi prestasi yang cukup penting karena persediaan logistik sangat diperlukan oleh masyarakat pada saat itu (Atori, wawancara tanggal 28 Mei 2012; koleksi rekaman Fauz Nur'alim).

Selain melakukan pelucutan sejata, Untuk memudahkan koordinasi antara badan-badan perjuangan yang ada pada 19 September 1945 di bentuk Markas Daerah Perjuangan Pertahanan Priagan (MDPPP). Pembentukan organisasi ini dilatari juga karena keterbatasan jumlah senjata yang dimiliki oleh masing-masing badan perjuangan, sehingga memunculkan keinginan untuk bersatu dan dapat diharapkan dapat memudahkan garis perjuangan. Kemudian pada 12 Februari 1946 MDPPP diganti menjadi Majelis Persatuan Pertahanan Priangan (MPPP) ${ }^{4}$ yang diketuai oleh Kamran dari Lasykar Hizbullah Priangan.

\section{b. Peristiwa Bandung Lautan Api}

\footnotetext{
${ }^{4}$ MPPP terdiri atas 61 unsur organisasi sipil dan militer.
}

Pada akhir 1945 hingga 23 Maret 1946 terjadi serangkaian pertempuran antara pihak Indonesia dengan BelandaSekutu yang diwakili oleh Inggris di Bandung. Peristiwa itu lazimnya disebut Palagan Bandung atau "Bandung Lautan Api". Kejadian ini bermula ketika pasukan Inggris yang ditempatkan di Bandung di bawah pimpinan Jenderal D.C. Hawthorn mengeluarkan tuntutan untuk mengambil para tawanan Jepang yang pada saat itu ditahan oleh badan-badan perjuangan bersama TNI-Divisi Siliwangi. Selain itu mereka juga menuntut agar mereka menyerahkan Kota Bandung, 29 November 1945. Permintaan tersebut mendapatkan penolakan dari badan-badan perjuangan - tentu ada Lasykar Hizbullah di dalamnya - yang tergabung ke dalam Majelis Persatuan Perjuangan Priangan (MPPP) dan TNI-Divisi Siliwangi sebagai tentara Republik. Oleh karena itu, pihak Inggris menganggap barisan badan perjuangan yang ada di Bandung dan juga TNI-Divisi Siliwangi adalah kelompok pengacau, teroris yang harus dikeluarkan dari Bandung (Suryanegara, 2010: 212).

Tidak ketinggalan Lasykar Hizbullah - dengan tokohnya Kamran dan Utarya - turut andil dalam peperangan ini bersama para santri-santri yang berasal dari pesantren sekitar Bandung.

Lasykar Hizbullah dengan semangat tinggi dan persenjataan alakadarnya melakukan perlawanan secara berani. Bahkan keberaniannya itu melebihi anggota-anggota dari anggota badan perjuangan lainnya. Misal saat pertempuran yang terjadi di Jl. Lengkong Besar berlangsung, pernah ada dua orang anggota dari Lasykar Hizbullah dari Batalyon Huseinsyah yang berani menyerbu pasukan Belanda-Sekutu hingga menaiki tank baja (panser) dari pasukan Gurkha, hanya dengan berbekal golok, pedang dan bambu runcing (Endan, wawancara 8 Juni 2015). 


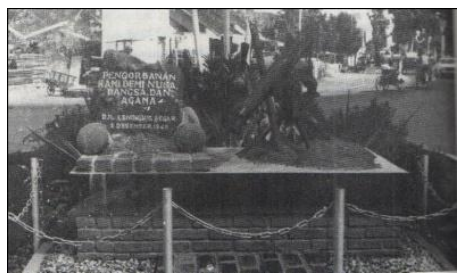

Gambar 3. Monumen Perjuangan Lasykar Hizbullah di Jl. Lengkong Besar Bandung

Sumber: Suryanegara, 2010: 212.

Machdar (wawancara tanggal 13 Juni 2015) memaparkan, biasanya sebelum para santri yang tergabung ke dalam Lasykar Hizbullah diterjunkan ke dalam medan pertempuran, mereka diharuskan terlebih dahulu melakukan zikir (wirid). Hal itu dimaksudkan sebagai pembinaan mental agar lebih berani dan tangguh dalam setiap kali melakukan pertempuran. Dalam proses wiridan, dipimpin oleh seorang kyai atau orang yang ditunjuk oleh kyai atas dasar kecakapan dan keluhuran tentang ilmu agama. Selain itu, diberikan juga gemblengan atau ceramah-ceramah mengenai peperangan (jihad): hukum perang melawan orang kuffur, kedudukan orang yang gugur di medan tempur (syahid), dan hal-hal lainnya yang sesuai dengan ke-Islam-an.

Lasykar Hizbullah didukung oleh anggota yang paling banyak jumlahnya. Sayangnya, meskipun didukung dengan keberanian yang maksimal serta keanggotaan yang banyak jumlahnya, kerap kali dalam setiap pertempuran tidak disertai dengan perhitungan-perhitungan kemiliteran secara matang. Akibatnya tidak sedikit dari mereka yang mati secara sia-sia atau "mati konyol" (Suryana, wawancara 10 Juni 2015).

Sementara Tentara Republik yang tergabung dalam Divisi Siliwangi pimpinan Kolonel Nasution, merupakan satu-satunya kesatuan tentara yang memiliki sruktur organisasi paling baik di antara kesatuan-kesatuan yang ada. Namun Divisi Siliwangi tidak didukung oleh kelengkapan persenjataan yang memadai dibanding kesatuan-kesatuan lainnya. Minimnya persenjataan yang dimiliki
Divisi Siliwangi membuat mereka sulit untuk dapat mempertahankan Bandung dari pendudukan Belanda-Sekutu.

Sebagai konsekuensi kekalahannya itu, selanjutnya Lasykar Hizbullah dan badan-badan perjuangan lainnya (MPPP) menarik mundur pasukannya meninggalkan Kota Bandung bersamasama dengan TNI-Divisi Siliwangi. Mereka mengungsi ke daerah-daerah di sekitar Bandung Selatan. Di sana, lalu MPPP mendirikan markas baru di daerah Ciparay dan TNI-Divisi Siliwangi bermarkas di daerah Cicalengka. Kemudian, keduanya pindah lebih jauh lagi ke sebelah tenggara Bandung, dan membentuk markas besarnya di Garut (Van Dijk, 1983: 69).

Di luar Bandung, bahkan terdapat pula anggota Lasykar Hizbullah yang berasal dari pesantren-pesantren dari Garut. Di Garut, selanjutnya MPPP membentuk Resimen Tentara Perjuangan yang terdiri atas lima batalyon. Satu dari kelima batalyon itu berasal dari Lasykar Hizbullah Huseinsyah. ${ }^{5}$

\section{c. Agresi Militer Belanda I}

Peranan Lasykar Hizbullah di Priangan semakin menampakkan dirinya ketika terjadi Agresi Militer Belanda (AMB) pertama pada tanggal 20 Juli 1947. Akibat dari aksi "polisional"6 pertama ini menimbulkan kerugian yang sangat besar bagi struktur militer dan administrasi di sejumlah kota-kota di Jawa Barat, terutama Kota Bandung sebagai ibukota Karesidenan Priangan, sekaligus ibukota Provinsi Jawa Barat.

\footnotetext{
5 Keempat batalyon lainnya adalah: Garuda Hitam, terdiri atas bekas satuan-satuan BPRI dan dipimpin oleh Mayor Rivai. Batalyon Taruna Jaya, terdiri atas satun-satuan Pesindo di bawah pimpinan Mayor Sudarman; Batalyon Barisan Banteng Republik Indonesia dipimpin oleh Kapten Rachmat Sulaeman; dan Batalyon Gabungan dikepalai Mayor Pelupessy (Peranan, 1965: 50; Van Dijk, 1983: 70).

6 Nama lain dari Agresi Militer yang dilancarkan pihak Belanda.
} 
Pada saat peristiwa ini berlangsung, pihak Belanda mengerahkan kekuatan sebanyak dua divisi untuk wilayah Jawa Barat dengan persenjataan yang lengkap dan modern. Tujuannya, selain untuk memperluas wilayah pendudukan, juga ditujukan untuk menguasai wilayahwilayah yang memiliki potensi perekonomian tinggi seperti di wilayah Priangan yang kaya dengan hasil-hasil perkebunannya.

Pasukan TNI dan Lasykar Perjuangan tampak menanggung beban yang sangat berat menghadapi seranganserangan ini. Pasukan Belanda yang dipimpin Kolonel "Tjantje" Meijer yang tergabung dalam Brigade V/Divisi B (2)/Mayor Jenderal De Wall bergerak dari Bandung menuju ke arah timur Bandung; Garut-Tasikmalaya-Ciamis, lalu ke Jawa Tengah. Sementara Pasukan Belanda dari arah Jakarta menuju Bandung dihadapi oleh Brigade III TNI dengan bantuan dari Batalyon Hizbullah pimpinan Mayor Taberani di sektor Padalarang. Situasi yang kurang menguntungkan dan kalah dalam segi persenjataan membuat perlawanan TNI dan Hizbullah di wilayah ini dengan mudah dapat dikalahkan pasukan Belanda (Disjarahdam IV Siliwangi, 1979: 104).

Front timur Bandung yang menuju ke sekitar Garut juga mengalami hal serupa. Misalnya perlawanan dari Lasykar Hizbullah pimpinan KH. Anwar Musaddad dan KH. Yusuf Taujiri yang bermarkas di Pesantren Cipari. Pasukan Belanda berhasil menduduki Pesantren Cipari dan menawan kedua tokoh tersebut. Keduanya ditahan setelah Lasykar Hizbullah yang dipimpinnya melakukan aksi penyerangan terhadap pos-pos tentara Belanda di Wanaraja. Mereka ditahan di Sukadana Garut. Namun, atas bantuan Bupati Garut, Raden Padmanagara, mereka akhirnya dapat dibebaskan (Wildan, 2015: 5).

Dari sektor Malangbong, Lasykar Hizbullah diorganisir oleh S.M. Kartosuwiryo. Serangan dari Lasykar Hizbullah ini mampu memberikan perlawanan yang cukup baik dan membuat pasukan Belanda kewalahan mengahadapinya.

Keberadaan TNI-Brigade Guntur menjadi salah satu faktor sengitnya peperangan, selain juga diuntungkan karena posisi geografis Garut yang berupa pegunungan. Kesatuan TNI-Brigade Guntur menjadi partner dalam membangun pertahanan dengan Batalyon Hizbullah yang dikomandoi oleh Mayor Utarya. Kesatuan batalyon Hizbullah ini oleh Nasution diakui cukup solid karena keanggotaannya tersebar di tiap-tiap desa di wilayah itu (Bizawie, 2014: 313).

Oleh karena sengitnya pertempuran dan membuat Belanda kewalahan, akhirnya Belanda menerapkan penyerangan melalui operasi Blitzkrieg ${ }^{7}$. Suatu operasi militer yang dilakukan serentak dan terarah secara kilat. Berkat operasi Blitzkrieg-nya Belanda berhasil menduduki wilayah-wilayah Malangbong dan Malangbong tidak luput dari pendudukan Belanda, hingga Belanda berhasil membakar Institut Suffah yang dijadikan sebagai basis politik dan militer asuhan Kartosuwiryo (Dengel, 2011: 61).

\section{Respon Lasykar Hizbullah dalam menyikapi Fusi dengan TNI \\ Di bawah kepemimpinan Sudirman,}

TKR (sekarang: TNI) sebagai tentara negara selalu ditekankan sebagai alat pertahanan negara - sebagaimana yang kita yakini selama ini - bahwa tentara hanya memiliki satu kewajiban saja, yaitu mempertahankan kedaulatan negara dari kekuasaan asing. Selain itu, ditekankan pula pentingnya untuk menjalin kerja sama dengan badan-badan perjuangan.

Sepanjang tahun 1946, struktur komando masih belum teratur karena kesatuan masing-masing daerah seringkali bertindak sendiri-sendiri. Pengaturan sistem komando masih dalam taraf sosialisasi. Menyikapi keadaan seperti itu, lalu upaya peningkatan profesionalisme dan reorganisasi tentara semakin

\footnotetext{
7 Istilah ini pertama kali diperkenalkan oleh Pasukan Nazi (Jerman) pada saat PD II.
} 
ditingkatkan lagi oleh pemerintah guna menghasilkan tentara yang profesional dan efisien. Sebuah langkah yang dilakukan pemerintah untuk mencapai hal itu yaitu dengan membentuk Panitia Besar untuk mereorganisasi ketentaraan dengan Letjen Oerip Soemohardjo duduk sebagai ketuanya (Sundhaussen, 1986: 17). Tujuannya dimaksudkan untuk penataan kembali struktur komando dan pengaturan kesatuan-kesatuan tentara yang telah ada.

$\begin{array}{llll}\text { Pada } & 23 & \text { Februari } 1946\end{array}$

diselenggarakan reorganisasi tentara oleh pemerintah Indonesia yang bertugas menentukan kebijakan-kebijakan persoalan pertahanan, organisasi tentara, dan kedudukan badan-badan perjuangan. Berdasarkan kedudukan yang dikeluarkan oleh Menteri Pertahanan dinyatakan bahwa badan-badan perjuangan diharuskan melebur menjadi satu ke dalam organisasi ketentaraan resmi, yaitu TRI. Dalam waktu tiga bulan badan-badan perjuangan didisiplinkan dan dibina untuk di militerisasi (Suryana, wawancara tanggal 10 Juni 2015).

Kemudian sebagai hasil realisasi peleburan antara organisasi tentara regular yang saat itu bernama TRI dengan badanbadan perjuangan disepakatilah nama TNI sebagai nama lembaganya. Dengan begitu, nama TRI diganti menjadi TNI (Sin Po, No. 882. 5 Oktober 1948).

Pada 3 Juni 1947 secara resmi TRI dan badan-badan perjuangan bergabung ke dalam satu wadah tentara regular bernama TNI. Panglima Soedirman duduk sebagai Panglima Besar TNI (Poesponegoro, dan Nugroho Notosusanto, 1993: 147). Keputusan itu diperkuat dalam penetapan Berita Negara No. 24 tahun 1947, yang berbunyi:

1. Mulai tanggal 3 Juni 1947 secara resmi disahkan berdirinya Tentara Nasional Indonesia (TNI);

2. Segenap anggota angkatan perang dan segenap laskar-laskar bersenjata mulai saat ini dimasukkan ke dalam TNI; dan
3. Pucuk pimpinan TNI berada di bawah komando Panglima Besar TNI (Bizawie, 2014: 290-291).

Di Priangan, anggota Lasykar Hizbullah menanggapinya dengan beragam keinginan dari pemerintah itu. Ada yang menanggapi secara positif, namun ada juga yang menolak dan bersifat antagonistik. Meski di dalam internal Hizbullah Priangan terjadi ketidaksolidan, umumnya mereka meresponnya secara positif. Satu di antaranya adalah Lasykar Hizbullah dari Batalyon Huseinsyah dari Resimen Tentara Perjuangan di bawah koordinasi MPPP pada tanggal 17 Mei 1947 bergabung dengan TNI. Hasil dari unifikasi itu kemudian melahirkan kesatuan Resimen Kesembilan Brigade Guntur yang menjadi Resimen kedua dalam Divisi Siliwangi (Van Dijk, 1983: 70).

Kesediaan Lasykar Hizbullah bergabung dengan TNI-Divisi Siliwangi itu bukan tanpa alasan. Pertimbangannya karena Masyumi pada saat itu berposisi sebagai partai (koalisi) pemerintah, dan Lasykar Hizbullah sebagai sayap kemiliteran Masyumi membuat Lasykar Hizbullah bersifat akomodatif dengan pemerintah Republik Indonesia. Faktor lainnya karena keterbatasan senjata yang dimiliki Lasykar Hizbullah, sehingga membulatkan tekad mereka untuk menyatu dengan TNI.

Sementara itu di Garut, terdapat Lasykar Hizbullah dari Pesantren Al-Falah Biru di bawah pimpinan KH. Syaikhuna Badruzzaman. Pada tahun 1948, KH. Syaikhuna Badruzzaman menyarankan kepada anggotanya untuk bergabung dan melebur dengan TNI. Usulan itu mendapatkan respon positif dari beberapa anggota Lasykar Hizbullah. Mereka di antaranya adalah: Aos Sumandar, pangkat terakhir Kapten dengan Jabatan Danramil Wanaraja; Oom Jailani, jabatan terakhir Letnan Polisi, Pengawal Presiden; Hamim Ahyar, pangkat terakhir Letnan Dua; Enis Idris, pangkat terakhir Letnan Satu; dan Abdul Galib, pangkat terakhir Sersan Mayor (Muhsin Z, 2011: 60). 
Kesatuan-kesatuan Hizbullah dalam TNI melebur ke dalam kesatuan setingkat brigade, resimen, batalion, dan seksi pasukan dalam organisasi TNI. Dengan begitu, para perwira dalam kesatuan Hizbullah yang menempati kedudukan di masing-masing jenjang kesatuan berhak mengenakan jenjang kepangkatan sebagaimana yang diatur dan berlaku dalam kesatuan TNI. Contoh, KH. Zainul Arifin (Pemimpin Besar Hizbullah) mendapat pangkat Mayor Jenderal karena posisi atau jabatannya sebagai Panglima Tinggi Hizbullah dan Huseinsyah dari Priangan berpangkat Mayor karena membawahi kesatuan batalion (Bizawie, 2014: 292-293).

Bersatunya Hizbullah dengan TNI, berarti telah mengikuti garis komando dan alokasi kesatuan TNI. Ada beberapa perubahan setelah Hizbullah melebur dengan TNI misalnya dari aspek hierarki organisasi dan jenjang kepangkatan. Hizbullah menghilangkan kesatuankesatuan satu tingkat dari sebelumnya. Satuan-satuan yang sebelumnya setingkat dengan divisi, turun satu tingkat menjadi resimen, resimen turun satu tingkat menjadi batalion, batalion menjadi kompikompi, kesatuan kompi menjadi peleton, dan kesatuan peleton turun satu tingkat menjadi regu.

Penyesuaian berlaku juga pada masalah kepangkatan dari para perwira yang membawahi kesatuan. Jika sebelumnya berpangkat Letnan Kolonel karena membawahi resimen, maka diturunkan satu tingkat menjadi Mayor membawahi batalion, juga dari Mayor menjadi Kapten membawahi kesatuan kompi, dan seterusnya (Endan, wawancara tanggal 8 Juni 2015).

Bagi yang menolak peleburan dengan TNI, disebabkan perbedaan ideologi dan garis perjuangan. Ada pula yang menolak, karena ketidaksiapan mereka harus terikat oleh sistem keprajuritan. Baginya perjuangan yang mereka lakukan hanya sebatas untuk memperjuangkan kemerdekaan Indonesia.
Setelahnya, mereka akan kembali lagi ke rumahnya masing-masing dan melakukan kehidupan seperti sedia kala. Umumnya mereka kembali bertani atau ke pesantrenpesantren (Endan, wawancara tanggal 8 Juni 2015).

Dengan melihat uraian di atas, dapat disimpulkan, adanya instruksi pemerintah untuk diadakannya peleburan Lasykar Hizbullah ini menuai polemik dalam sepanjang perjalanannya dan menjadikan kekuatan Lasykar Hizbullah terpecah menjadi dua bagian; pro-pemerintah dan kontra-pemerintah.

Lasykar Hizbullah yang tergolong kontra-pemerintah karena disebabkan perbedaan garis perjuangan negara adalah Lasykar Hizbullah kelompok Kartosuwiryo, di antaranya: Kamran (ketua MPPP yang kelak menjadi panglima TII), Raden Oni Syahroni, Ateng Djaelani, Zainal Abidin.

Dengel

(2011: menyebutkan, Utarya pernah menemui dan membujuk Kamran dan S.M. Kartosuwiro agar mereka dan para pengikutnya bersedia untuk bergabung dengan TNI dan bersama-sama berjuang melawan BelandaSekutu. Namun usaha itu tidak membuahkan hasil, sebaliknya Utarya pada saat itu mati terbunuh. Dengel tidak menyebutkan alasan dan pelaku pembunuhan itu, tapi diperkirakan dilakukan oleh kelompok Kartosuwiryo yang sebelumnya bersitegang akibat usaha dari Utarya tersebut dan perbedaan paham dari keduanya.

Pernyataan Dengel diamini oleh Van Dijk - yang merupakan peneliti tentang DI/TII juga. Van Dijk menyebutkan peleburan Resimen Tentara Perjuangan ke dalam Divisi Siliwangi awalnya dihalangi oleh Kamran, dengan melukiskan Kamran yang menjadi ketua MPPP ketika itu, sangat berambisi untuk menjadi "Jenderal". Namun usahanya itu sia-sia dalam mencegah meleburnya Lasykar Hizbullah ke dalam TNI - Divisi Siliwangi (Siliwangi, 1968: 184; Van Dijk, 1983: 70). 
Perpecahan itu semakin memucak ketika disepakatinya Perjanjian Renville pada 17 Januari 1948 yang mendorong anggota Lasykar Hizbullah di bawah Kartosuwiryo semakin menunjukkan sikap penentangannya terhadap pemerintah Republik Indonesia. Salah satu isi kesepakatannya adalah pengosongan wilayah kekuasaan RI terhadap daerah yang dikuasai oleh Belanda. Oleh karena itu, TNI-Divisi Siliwangi dan badan-badan perjuangan lainnya harus melakukan "Hijrah" ke Jogjakarta. Pasukan Divisi Siliwangi yang merupakan tentara regular di Jawa Barat harus mematuhi hasil perjanjian yang telah disepakati. Pada bulan Februari 1948 sekitar 35.000 pasukan Divisi Siliwangi pergi meninggalkan Jawa Barat menuju Jogjakarta.

Sementara itu, Lasykar Hizbullah (kontra-pemerintah) yang tersisa sekitar 4.000 personel menolak untuk hijrah. Mereka menganggap pemerintah Republik telah menjual Jawa Barat kepada Belanda. Itulah sebabnya, S.M. Kartosuwiryo yang pada waktu itu menjadi Pengurus Masyumi daerah Jawa Barat - memilih tetap berada di Jawa Barat (tidak melakukan hijrah) untuk melakukan perang gerilya dengan tentara Belanda (Kahin, 1970: 234; Lubis, et.al., 2013: 330).

Selama Jawa Barat dikosongkan dari kekuatan TNI-Divisi Siliwangi, S.M. Kartosuwirjo bersama Lasykar Hizbullahnya terus melakukan pertempuran gerilya melawan Belanda, seraya melakukan konsolidasi untuk mendirikan Negara Islam di Jawa Barat.

Pada tanggal 10-11 Februari 1948 diadakan suatu konferensi di Pangwedusan Cisayong-Tasikmalaya. Dalam konferensi ini hadir 160 dari beberapa perwakilan organisasi Islam di Jawa Barat yang proKartosuwiryo, antara lain: dari Dahlan Lukman sebagai ketua GPII dan Siti Murtaji'ah ketua GPII Putri; Sanusi Pratawidjaja ketua Masyumi daerah Priangan; Kamran sebagai Komandan
Teritorial Hizbullah; Abdullah Ridwan ketua Hizbullah Priangan dan Raden Oni Syahroni Panglima Sabilillah Priangan; sebagai ketua Masyumi cabang Garut hadir Saefullah (Dengel, 2011: 65).

Dalam konferensi ini beberapa perwakilan organisasi Islam tersebut mengusulkan pendapatnya, antara lain: Kamran wakil dari Lasykar Hizbullah, menuntut agar pemerintah Indonesia membatalkan Pejanjian Renville dengan pihak Belanda. Apabila Indonesia tidak sanggup membatalkan hasil Perjanjian Renville, menurutnya lebih baik negara ini dibubarkan saja dan membentuk pemerintahan dengan corak baru, yakni Islam; lalu Affandi Ridwan dari GPII menyuarakan kepada pemerintah RI di Jogjakarta agar pemerintah Indonesia menyerahkan Jawa Barat kepada umat Islam - yang diwakili oleh mereka yang tetap tinggal dan tidak melaksanakan politik hijrah-nya ke Jogjakarta (DI/TII) (Dengel, 2011: 66).

Keputusan terpenting lainnya dalam konferensi itu adalah membekukan Masyumi wilayah Jawa Barat. Kartosuwiryo menilai, sudah saatnya Islam dijadikan sebagai haluan bernegara, bukan sebagai landasan organisasi. Pembekuan Masyumi semakin dipertegas dengan dibentuknya Madjlis Islam (MI) yang dipimpin oleh Kartosuwiryo sendiri selaku Imam. Terakhir, adalah pembentukan Tentara Islam Indonesia (TII) yang diambil dari Lasykar Hizbullah, GPII, serta organisasi Islam lainnya yang se-ideologi dengan Kartosuwiryo. Peleburan Lasykar Hizbullah ke dalam TII, berarti dimulainya diperkenalkan istilah Tentara Islam Indonesia (TII) sebagai benteng utama Darul Islam (DI) atau Negara Islam Indonesia (NII) ciptaan Kartosuwiryo dan berakhirnya penamaan Lasykar Hizbullah di Priangan.

\section{PENUTUP}

Dari paparan di atas dapat dikemukakan bahwa Lasykar Hizbullah merupakan salah satu badan perjuangan 
yang pernah ada di Priangan bahkan di Jawa Barat. Secara hierarki, Lasykar Hizbullah di Priangan merupakan organisasi sayap kepemudaan yang berada di bawah naungan Masyumi Karesidenan Priangan. Lasykar Hizbullah di Priangan dibentuk pada 10 Januari 1945 setelah sebelumnya Masyumi Karesidenan Priangan mendapatkan instruksi dari PB. Masyumi di Jakarta untuk mendirikan Lasykar Hizbullah di tiap karesidenan di Indonesia. Dengan kata lain, Lasykar Hizbullah Priangan merupakan kepanjangan tangan Lasykar Hizbullah pada tingkat pusat atau nasional, sehingga tujuan pembentukannya pun tidak jauh berbeda yakni untuk membela dan menegakkan kedaulatan agama (Islam), dan kedaulatan negara dari kekuasaan asing (Sekutu-Belanda).

Peranan yang ditorehkan Lasykar Hizbullah di Priangan memiliki arti penting bagi perjuangan kemerdekaan Indonesia antara lain: pertama, keterlibatan mereka (ulama-santri) dapat menjadi sumber kekuatan utama yang dimiliki rakyat Priangan-di samping badan-badan perjuangan lainnya dan BKR/TKR (sekarang TNI) - dalam melawan kekuatan Sekutu-Belanda mengingat jumlah anggota Lasykar Hizbullah di Priangan menyandang predikat terbanyak dibanding anggota badan-badan perjuangan lainnya yang pernah ada di Priangan. Hal ini disebabkan karena di wilayah Priangan banyak terdapat pesantren-pesantren (santri) yang menjadi sumber utama Lasykar Hizbullah. Hubungan santri dengan kyai/ajengan yang bersifat "patrion-client" memudahkan seorang kyai/ajengan dalam memobilisasi para santri untuk turut ke dalam medan pertempuran.

Untuk memudahkan koordinasi dengan Badan-Badan Perjuangan lainnya dalam melawan Sekutu-Belanda, Lasykar Hizbullah tergabung ke dalam MDPPP (Majelis Daerah Perjuangan Pertahanan Priangan). Selanjutnya pada 12 Februari 1946 MDPPP diganti menjadi MPPP
(Majelis Persatuan Pertahanan Priangan), ketuanya adalah Kamran dari Lasykar Hizbullah.

Kedua, anggota Lasykar Hizbullah di Priangan memiliki keberanian yang sangat tinggi dalam melakukan peperangan. Biasanya, sebelum para santri yang tergabung ke dalam Lasykar Hizbullah diterjunkan ke dalam medan pertempuran, mereka diharuskan terlebih dahulu melakukan zikir (wirid). Hal itu dimaksudkan sebagai pembinaan mental agar lebih berani dan tangguh dalam setiap kali melakukan pertempuran. Proses wiridan, dipimpin oleh seorang kyai/ajengan atau orang yang ditunjuk oleh kyai/ajengan atas dasar kecakapan dan keluhuran tentang ilmu agama. Selain itu, diberikan juga gemblengan atau ceramah-ceramah mengenai peperangan (jihad): hukum perang melawan orang kuffur, kedudukan orang yang gugur di medan tempur (syahid), dan hal-hal lainnya yang sesuai dengan ke-Islam-an.

Misalnya, pada saat pertempuran di Jl. Lengkong Besar - Bandung yang terjadi pada 29 November 1945, ada beberapa anggota Lasykar Hizbullah dari Batalyon Huseinsyah yang sangat berani menyerang tentara Sekutu secara brutal-menaiki tank baja-dengan bermodalkan senjata sederhana seperti bambu runcing dan golok.

Ketiga, menjadi bukti sejarah bahwa peran dan kontribusi ulama-santri tidak lagi diragukan keberadaannya di dalam panggung sejarah Indonesia umumnya, dan pada tingkat lokal secara khusus.

Pada perjalanannya, Lasykar Hizbullah terpecah menjadi dua golongan, golongan pro-pemerintah dan kontrapemerintah. Benih-benih perpecahan itu bermula ketika diterapkannya fusi dengan TNI pada 1947. Kedua, ketika menyikapi hasil Perjanjian Renville di akhir 1947. Lebih jauh lagi sebetulnya perpecahan itu dilatari karena adanya perbedaan ideologis. Bagi Lasykar Hizbullah yang kontrapemerintah RI kemudian mereka menjelma menjadi sumber kekuatan utama Tentara 
Islam Indonesia (TII) yang memperjuangkan berdirinya Negara Islam Indonesia (NII) di bawah Imam Kartosuwiryo. Sejak dibentuknya Tentara Islam Indonesia (TII) berdasarkan hasil Konferensi Cisayong pada 10-11 Februari 1948, maka berakhirlah eksistensi Lasykar Hizbullah di Priangan.

\section{E. UCAPAN TERIMA KASIH}

Penghargaan dan terima kasih yang tak terhingga penulis ucapkan kepada Bapak Dr. Mumuh Muhsin Z., M.Hum dan Bapak Kunto Sofianto, Ph.D., yang telah memberikan bimbingan dan arahan berkenaan dengan penelitian dan penulisan artikel ini. Ucapan terima kasih juga penulis sampaikan kepada Letkol Eko Iswanto selaku Kepala Pusjarah TNI AD dan para narasumber (pelaku atau saksi sejarah) yang telah banyak membantu penulis dalam melakukan penelitian dengan memberikan informasi dan sumber-sumber yang penulis butuhkan untuk menulis artikel ini.

\section{DAFTAR SUMBER}

\section{Surat Kabar}

Asia Raya. No. 11. 12 Januari 1945.

Djiwa Islam. No. Setahun GPII. 1946-1948.

Sin Po. No. 882. 5 Oktober 1948.

Soeara Moeslimin. No. 23, No. 24. 15 Desember 1944.

No. 2. 15 Januari 1945.

.No. 6. 15 Maret 1945.

No. 10. 1 Mei 1945.

\section{Buku dan Makalah}

Bizawie, Zainul Milal. 2014. Laskar Ulama-Santri dan Resolusi Jihad: Garda Menegakkan Indonesia 1945-1949. Jakarta: Pustaka Compass.

Dengel, Holk. H. 1995.
Darul Islam-NII dan Kartosuwiryo: Angan-angan yang Gagal. Jakarta: PT. Pustaka Sinar Harapan.

van Dijk, Cornelis 1983.

Darul Islam: Sebuah Pemberontakan. Jakarta: Grafiti Pers.

Disjarahdam VI/Siliwangi. 1979.

Siliwangi dari Masa ke Masa: Cetakan kedua. Bandung: Angkasa.

Gottschalk, Louis. 1985. Mengerti Sejarah. Terj. Nugroho Notosusanto. Jakarta : UI Press.

Herlina, Nina. 2011. Metode Sejarah. Bandung: Satya Historika.

Kusdiana, Ading. 2014.

Sejarah Pesantren: Jejak, Penyebaran, dan Jaringannya di Wilayah Priangan (1800-1945). Bandung: Humaniora.

Lubis, et.al., 2011.

Sejarah Perkembangan Islam di Jawa Barat. Bandung: Yayasan Masyarakat Sejarawan Indonesia Cabang Jawa Barat.

-------, et.al., 2013.

Sejarah Provinsi Jawa Barat Jilid 2. Bandung: Yayasan Masyarakat Sejarawan Indonesia Cabang Jawa Barat.

Muhsin, Mumuh Z. 2011.

$\begin{array}{lcc}\text { Perjuangan K.H. } & \text { Syaikhuna } \\ \text { Badruzzaman dalam } & \text { Merebut, } \\ \text { Mempertahankan, dan } & \text { Mengisi } \\ \text { Kemerdekaan (1900 } & \text { 1972). } \\ \text { Jatinangor: Jurusan Sejarah } & \text { Fakultas } \\ \text { Sastra Unpad. [E-Book]. } & \end{array}$

Notosusanto, Nugroho. 1979.

Tentara PETA pada Jaman Pendudukan Jepang di Indonesia. Jakarta: Gramedia.

Poesponegoro, M. D. dan Nugroho Notosusanto. 1993.

Sejarah Nasional Indonesia VI: Cetakan Kedelapan. Jakarta: Balai Pustaka.

Ritzer, George dan Douglas J. Goodman. 2011. Teori Sosiologi Modern: Edisi ke-6. Jakarta: Kencana

Soekanto, Soerjono. 1982. 
Sosiologi Suatu Pengantar. Jakarta:

Raja Grafindo Persada.

Sundhaussen, Ulf. 1986.

Politik Militer Indonesia 1945-1967:

Menuju Dwifungsi ABRI. Jakarta: LP3S.

Suryanegara, Ahmad Mansyur. 1996.

Pemberontakan Tentara Peta di

Cileunca Pangalengan Bandung

Selatan. Jakarta: Yayasan Wira Patria

Mandiri.

2010.

Api Sejarah 2. Bandung: Grafindo Media Pratama.

Wildan, Dadan. 2015.

Prof. KH. Anwar Musaddad: Ulama Multikultural, Akademisi Paripurna, dan Politisi Moderat. Disampaikan dalam Seminar Nasional Pengusulan KH. Anwar Musaddad sebagai Pahlawan Nasional.

\section{Sumber Lisan}

Atori, Muhammad (84 tahun). Eks-Lasykar Hizbullah. Pewawancara, Fauz Nur'alim. Garut, tanggal 28 Mei 2012.

Djuju, Momod (83 tahun). Eks-Lasykar Pangeran Papak. Pewawancara, Fauz Nur'alim. Garut, tanggal 3 Juni 2012.

Endan, Tatang (85 tahun). 2015.

Saksi Sejarah/Eks-Lasykar Pemuda Republik Indonesia. Wawancara, Bandung, 8 Juni 2015.

Machdar, Moehammad. (87 tahun). 2015.

Eks-Lasykar Hizbullah. Wawancara, Bandung, 13 Juni 2015.

Suryana, Nana. (92 tahun). 2015.

Eks-Lasykar Hizbullah. Wawancara, Bandung, 10 Juni 2015 